\title{
Region 8 Radiological Assistance Program Team Response Manual
}

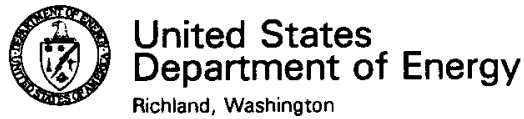

Richland, Washington 
LEEAL DISCLAMER

This report was prepered as on eccount of work sponsored by an ageney of the United States Government. Neither the United States Government nor any agency thereof, nor any of their emplovees, nor any of their contrectors, subcontractors or their employees, makes any warranty, express or implied, or assumes any legal liability or responsibility for the accuracy, completeness, or any third party's use or the results of such use of any information, apparatus, product, or process disciosed, or represents that its use would not infringe privately owned rights. Reference herein to any specific commercial product, process, or service by trade name, trademark, menufacturer, or otherwise, does not necessarily constitute or imply its endorsement, recommendation, or favoring by the United States Government or any agency thereof or its contractors or subcontractors. The views and opinions of authors expressed herein do not necessarily state or refiect those of the United States Government or any agency thereof.

This report has been reproduced from the best available copy. Available in paper copy and microfiche.

Available to the U.S. Department of Energy and its contractors from

Office of Scientific and Technical Information

P.O. Box 62

Oak Ridge, TN 37831

(615) 576-8401

Available to the public from the U.S. Department of Commerce National Technical Information Service

5285 Port Royal Road

Springfield, VA 22161

(703) $487-4650$

Printed in the United States of Americe

DISCLM-1.CHP (1-91) 


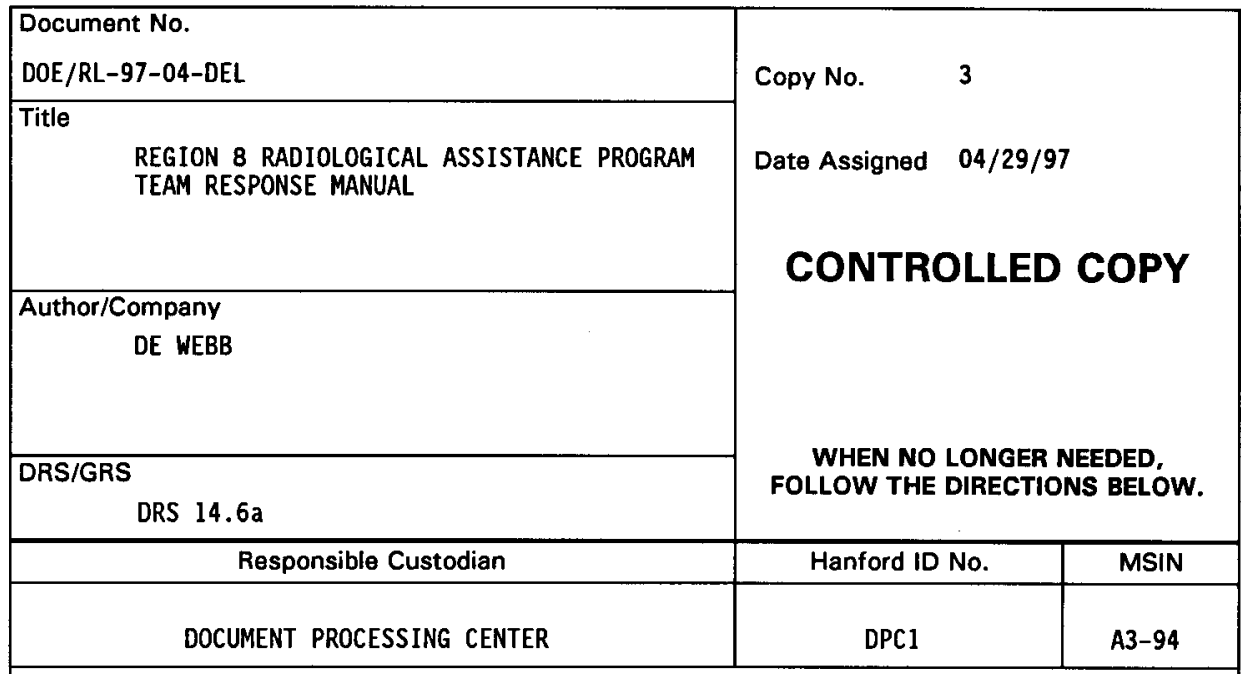

This is a CONTROLLED Document. The assigned custodian is responsible for this copy.

\section{TO REASSIGN OR RETURN DOCUMENT}

TO RETURN: When document is no longer needed, please recycle/destroy contents and binder, sign and date this UDC Unclassified Coversheet and return it indicating "Destroyed" to the address below.

TO REASSIGN: Fill out the NEW custodian's information below, return this Coversheet to UDC A3-95 and give the document to the new custodian.

To reassign, this form must be returned to A3-95.

\begin{tabular}{|l|l|l|}
\hline New Custodian & Hanford ID No. & MSIN \\
\hline & & \\
\hline
\end{tabular}

POSTAL MAIL:

Lockheed Martin Services, Inc.

P.O. Box 950/A3-95

Richland, WA 99352
PLANT MAIL:

Unclassified Document Control

$$
\text { A3-95 }
$$

376-6831 


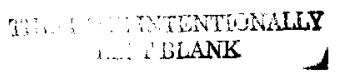




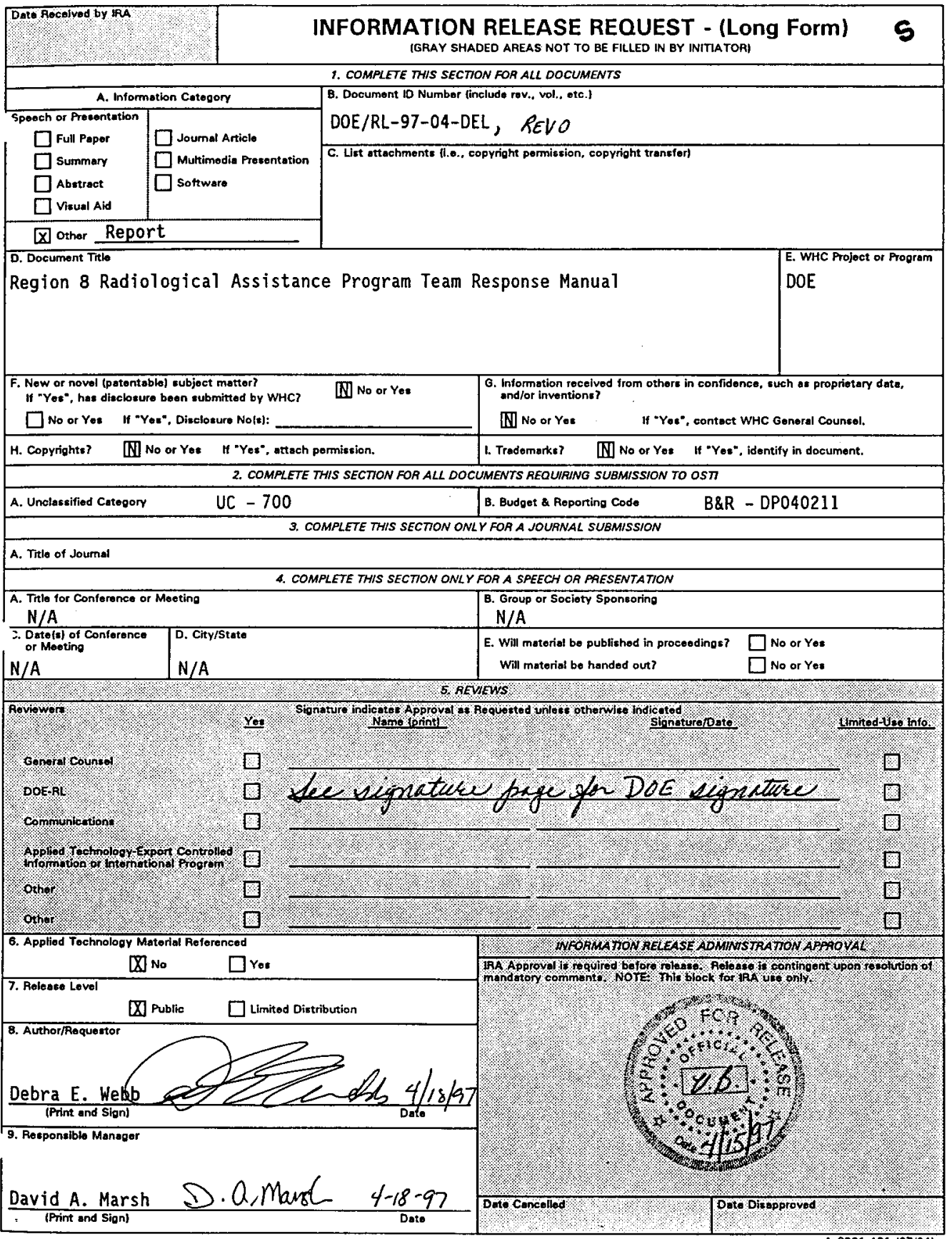


THE ' 5 T

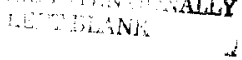




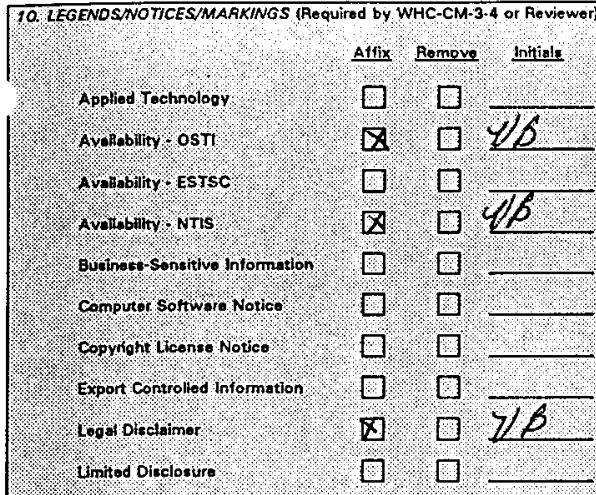

\section{MANDATOAY COMMENTS fLict onty mandatory comments here, to thitition}

12 DDDTTONAL INFOAMATION/COMMENTS:
Affix femoves intials

official Use only

Potont status:

Prodecisional information

Pooprommatic Notsco

Proprietery linformation

Pupose ond Uro

The itedoit tertation

Tradenark Disclaimor

other

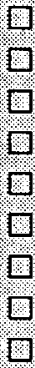

Rovewor Ifrint $\alpha$ sion
Resolved by Author/Requentor (Print 2 Sign)

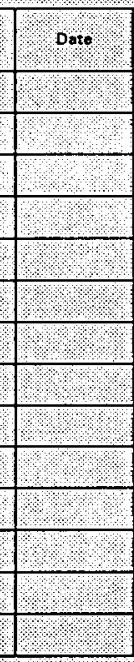




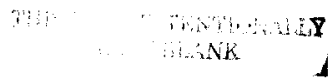


Document Titie: REGION 8 RADIOLOGICAL ASSISTANCE PROGRAM TEAM RESPONSE MANUAL

Approved by:

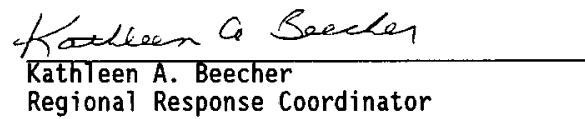

$\frac{\text { Qpine 3, } 1997}{\text { Date }}$

Regiona] Response Coordinator 
DOE/RL-97-04-DEL

This page intentionally left blank. 


\section{CONTENTS}

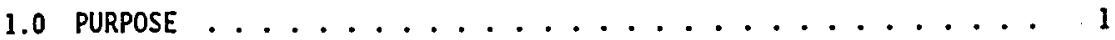

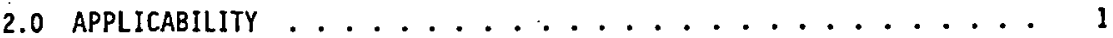

3.0 RESPONSIBILITIES .

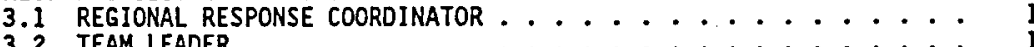

3.2 TEAM LEADER $\cdots \cdots \cdots$

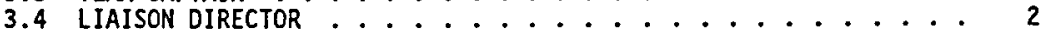

3.5 PUBLIC INFORMATION OFFICER ...................... 2

3.6 RESOURCE SUPPORT MANAGER ................... 2

3.7 FIELD TEAM LEADER ....................... 3

4.0 TEAM LEADER ..................... . . 5

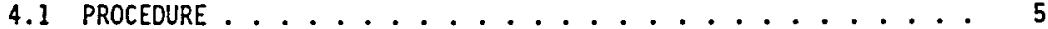

4.1.1 Receive the Request .............. 5

4.1 .2 Evaluate the Request . . . . . . . . . . 6

4.1.3 Enroute to the Scene Activities : . . . : 7

4.1.4 On-Scene Activities .............. 7

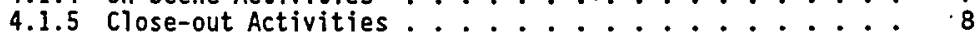

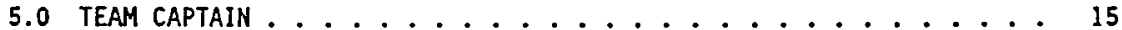

5.1 PROCEDURE . . . . . ............... 15

5.1.1 Receive and Evaluate the Request.......... 15

5.1 .2 On-Scene Activities .............. 16

5.1 .3 Close-out Activities ............. 17

5.2 FIVE DAY FINAL REPORT PROCEDURE . . . . . . . . 17

5.3 PROCEDURE FOR ACCESSING ENS (Personal Data Deleted) $\ldots$ is

6.0 LIAISON DIRECTOR . . . . . . . . . . . . . . 25

6.1 PROCEDURE . . . . . . . . . . . . . 25

6.1.1 On Receipt of Notification (Personal Data Deléted) 25

6.1 .2 On-Scene Activities ............. 25

6.1 .3 Close-Out Activities . . . . . . . . . 26

7.0 PUBLIC INFORMATION OFFICER .............. 29

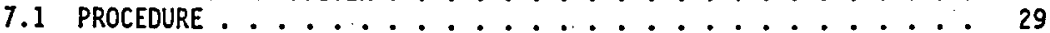

7.1 .1 On Receipt of Notification . . . . . . . 29

7.1 .2 On-Scene Activities ................. 29

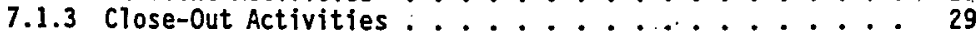

8.0 RESOURCE SUPPORT MANAGER ................. 33

8.1 PROCEDURE $\ldots \ldots$

8.1.1 on Receipt of Notification . . . . . 33

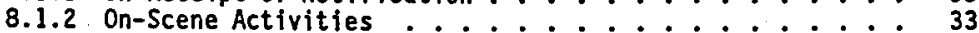

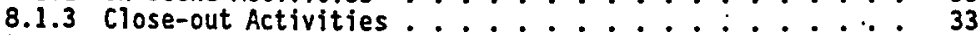




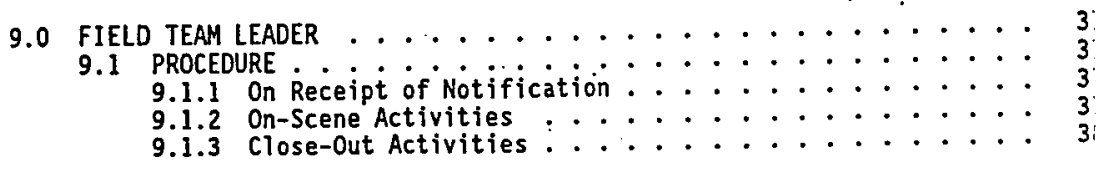

10.0 BIBLIOGRAPHY .................... 4 APPENDICES

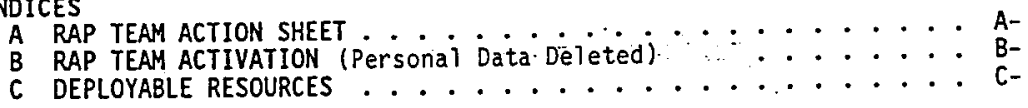

\section{LIST OF FORMS}

Radiological Assistance Program - Incident Report form . . . . . . Safety Plan Checklist.................. Team Leader Checkiist ................... . . . 1 Radiological Assistance Program - Incident Report Form ......... 1 Region 8 RAP Team Position and Deployment List .......... 2 Team Captain Checklist .................. 2 Liaison Director Checklist .................. 2 Public Information officer Checklist ............ 3 Resource Support Manager Checkl ist .............. 3 Field Team Leader Checklist................ 3

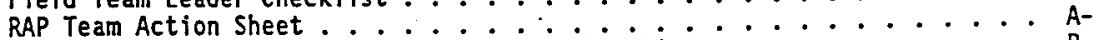
RAP Team Activation and 24 -Hour Notification List . . . . . . . B-

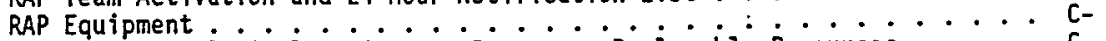
Region 8 Radiological Assistance Program - Depioyable Resources..... C-

\section{LIST OF TERMS}

$\begin{array}{ll}\text { ALARA } & \text { As Low As Reasonably Achievable } \\ \text { DOE } & \text { U.S. Department of Energy } \\ \text { ENS } & \text { Emergency Not ification System } \\ \text { EOC } & \text { Emergency Operations Center } \\ \text { HQ EOC } & \text { U.S. Department of Energy, Headquarters Emergency } \\ \text { Operations Center } \\ \text { LFA } & \text { Lead Federal Agency } \\ \text { PIO } & \text { Occurrence Not if ication Center } \\ \text { POC } & \text { Public Information Officer } \\ \text { RAP } & \text { Patrol Operation Center } \\ \text { RCO } & \text { Radiological Assistance Program } \\ \text { RL } & \text { Regional Coordinating Office } \\ \text { RRC } & \text { U.S. Department of Energy, Richland Operations Office } \\ & \text { Regional Response Coordinator }\end{array}$


DOE/RL-97-04-DEL.

\section{REGION 8 RADIOLOGICAL ASSISTANCE PROGRAM TEAM RESPONSE MANUAL}

\subsection{PURPOSE}

The purpose of this manual is to provide guidance so that a request for radiological assistance is responded to in an effective and consistent manner. These procedures are specific to the trained and qualified members of the Region 8 Radiological Assistance Program (RAP) team. Procedures provide steps for responding to the request, notification and activation of the team members, position descriptions, and checklists.

\subsection{APPLICABILITY}

The information in this manual includes operational procedures for the RAP team members. It includes forms that team members use to evaluate and document RAP responses, as well as personnel lists, equipment inventory lists, and regulatory documents which team members may need during team responses.

\subsection{RESPONSIBILITIES}

\subsection{REGIONAL RESPONSE COORDINATOR}

Review and approve this manual.

\subsection{TEAM LEADER}

The Team Leader shall be a Department of Energy (DOE) employee with experience and ability to work well with people and to communicate effectively both orally and in writing. The Team Leader deploys with the team. This individual represents the DOE when meeting the requestor or the On-Scene (Incident) Commander and may be acting as the Energy Senior Official (ESO) when the DOE is the Lead Federal Agency. This person is responsible for team safety, on-scene DOE operations, and will be making decisions as to the appropriateness of Team actions. The Team Leader assists in the integration of other agency emergency response activities. The Team Leader prepares and submits the Five Day Final Report. 
DOE/RL-97-04-DEL

\subsection{TEAM CAPTAIN}

The Team Captain is usually a DOE contractor employee with Health Physics and management experience. The Team Captain shall have the ability to work well with people and to communicate effectively both orally and in writing. The Team Captain deploys with the team. This individual directs the radiological response activities and ensures that radiological and non-radiological hazards have been identified. The Team Captain interprets and evaluates the radiological data, recommends mitigative actions, and communicates pertinent information to the Team Leader. The Team Captain is responsible to determine if and when the team's resources and expertise has been exceeded and shall request additional assistance. This individual provides on-scene direction and oversight to the RAP Team members, assuring that they are properiy equipped to safely enter hazardous areas and that radiation and other hazard exposure limits are As Low As Reasonably Achievable (ALARA). The Team Captain collects all radiological data, photographs, notes, records, etc., for compilation into the Five Day Final Report.

\subsection{LIAISON DIRECTOR}

The Liaison Director is usually a DOE employee with experience and ability to work well with people and to communicate effectively both orally and in writing. This individual does not deploy with the team, but remains at the Emergency Operations Center (EOC) to maintain a communications 1 ink among the deployed team, Hanford Site RL and Contractor management, DP-23 Duty Officer, and the DOE Headquarters EOC.

\subsection{PUBLIC INFORMATION OFFICER}

The Public Information officer (PIO) should be a DOE employee with expertise in external affairs, public information and media relations. The Public Information officer deploys with the team. This individual is the primary point of contact or liaison for providing information and/or briefings to the news media and/or public related to DOE radiological assistance activities. The Public Information officer is instrumental in providing to the RAP Team Leader any public or media concerns the team should be aware of.

\subsection{RESOURCE SUPPORT MANAGER}

The Resource Support Manager is usually a DOE contractor employee with experience in logistical management and experience in working well with people and to communicate effectively both orally and in writing. The Resource Support Manager deploys with the team. This individual ensures the operational readiness of the team's vehicles, equipment, and supplies. This person may coordinate team travel and provides logistical and communications support to the team. 


\subsection{FIELD TEAM LEADER}

The Field Team Leader is usually a DOE contractor employee with extensive operational health physics experience. The Field Team Leader must direct the field teams, have the ability to work with people and to effectively communicate both orally and in writing. The Field Team Leader deploys with the team. This individual provides on-scene direction to the field monitoring and sampling team(s) and ensures the team(s) conduct their field operations safely and practice ALARA. The Field Team Leader evaluates the data and determines field team operations. The Field Team Leader forwards collected field team data, photographs, notes, records, etc., to the Team Captain for compilation into the Five Day Final Report.

- Field Team members are usually DOE contractor employees. The Field Team members must have the ability to work with people and to effectively communicate both orally and in writing. The Field Team members deploy with the team(s). The Field Team members perform field measurements, document the results, and forward the results to the Field Team Leader. 
DOE/RL-97-04 -DEL

This page intentionally left blank. 


\subsection{TEAM LEADER}

\subsection{PROCEDURE}

As the Team Leader who has received a request for radiological assistance, complete the Radiological Assistance Program - Incident Report Form, attached to this procedure. This form provides the questions that must be answered so the Team Leader can receive, confirm, and/or verify the request, and respond accordingly. This procedure also addresses the steps to be taken when the RAP team has been notified to activate either automatically (i.e., by the ENS) or manually (individual phone call).

\subsubsection{Receive the Request}

1. As information is available, continue completion of the Radiological Assistance Program - Incident Report Form. Obtain the call-back number of the requestor.

2. Call the requestor and confirm or verify the request for radiological assistance. Ask the requestor if he/she has notified the appropriate authorities. Attempt to obtain a phone number of the Incident Commander and an event scene authority.

3. If the appropriate Federal or State agency has not been notified, complete that notification using the Federal and State agency phone numbers provided in the RAP Team Activation and 24-Hour Notification List, Appendix $B$ of this manual.

(NOTE: If the appropriate agency is the DOE, respond according to this procedure and assume the role of LFA On-Scene Senior Official until one arrives.)

4. Provide to that Federal or State agency the information you have obtained and assure them that the RAP will be available to them if they request.

5. If the appropriate Federal or State agency has been notified, provide them with any additional information, and prepare to respond if requested.

6. If the. Federal or State agency does not request assistance, take no further action except to complete the Radiological Assistance Program - Incident Report Form. Include in the Radiological Assistance Program - Incident Report Form any follow-up actions and forward the completed form to the Region 8 Regional Response Coordinator (RRC). 


\subsubsection{Evaluate the Request}

1. If the RAP has been requested, evaluate whether assistance can be provided over the telephone, or if a team deployment is required.

(NOTE: The Team Leader can call the Team Captain to assist as appropriate.)

2. Call the HQ EOC at (202) 586-8100, to notify them of a request for assistance, or delegate to the Team Captain. Provide the following to the HQ EOC.

- Your name

- Position/title

- RAP Region 8

- Situation, type of radiological incident and reason for call.

(NOTE: The HQ EOC shall be notified within 15 minutes after receipt of a request for emergency assistance.

Also, the HQ EOC shall be notified if additional assistance or resources are requested from another Regional Coordinating office [RCO] or when the incident may be subject to significant attention from the media.)

3. If assistance and/or advice can be provided over the telephone:

- Provide the advice.

- Complete the Radiological Assistance Program - Incident Report Form, noting the advice given, and forward the completed Radiological Assistance Program - Incident Report Form to the Region 8 RRC within four (4) working days of the response.

No further action is required.

4. If assistance cannot be provided over the telephone and team deployment is required, call the Patrol Operations Center (POC) 24-Hour Duty Officer at (509) 373-3800 and request activation of the RAP team.

(NOTE: If the Team Captain has not been called, do so now.)

a. Report to the EOC and obtain the Team Leader suitcase and portable cellular phones which are in the EOC, G-42. Ensure that extra batteries are available. Provide the phone number to the Resource Support Manager.

b. Prepare for a team briefing. This briefing should include:

- Roll call of responders (extra responders may remain to support the team deployment before returning to work or home). 
- Update/status of the event (information from the incident report form).

- Review of the Safety Plan with the team.

- Special instructions or considerations related to the response.

- Ensure the pre-deployment briefing includes aspects of transportation and Safety Plan Checklist (attached to this procedure).

c. Ensure that the requestor or event scene has been recalled for a status update and provide the team's estimated time of arrival.

\subsubsection{Enroute to the Scene Activities}

Prior to arrival, initiate and maintain communication with requestor or event scene and Liaison Director, to assure team has latest information regarding the event scene.

1. Set up a meeting location with the Incident Commander to receive a briefing upon arrival.

2. Obtain any new information from the Incident Commander and pass the information on to the team members.

\subsubsection{On-Scene Activities}

1. Arrive at the incident scene and report to the Incident Commander.

2. Obtain current status and any related information important to the RAP team on scene activities. If appropriate, assure the Public Information officer is present at this briefing.

3. Request that the Team Captain assist you in establishing, with the Incident Commander, radiological monitoring and assessment activities.

4. Maintain and complete the RAP Team Action Sheet (Appendix A) for the actions taken.

5. Brief the RAP team, or request that the Team Captain do so, and ensure that all team members are aware of the hazards, expectations, media involvement, etc.

6. Maintain communication with the Liaison Director.

7. Receive a periodic briefing and status of field team activities from the Team Captain. 


$$
\text { DOE/RL-97-04 -DEL }
$$

8. Maintain communications with the Team Captain to ensure the latest radiological data is passed forward and to relay pertinent data to the Incident Commander.

9. Request additional resources as required through the Liaison Director.

10. Determine when the team's response is to be terminated and communicate this to the Incident Commander.

\subsubsection{Close-out Activities}

1. Debrief with the RAP team and summarize response activities.

2. Debrief with the Incident Commander.

3. Communicate the team status and report the team's estimated arrival time in Richland to the Liaison Director.

4. On arrival at the EOC, debrief with the team. Ensure that a call to the $H Q E O C$ is made to report the team's safe arrival home.

5. Assure that all equipment and supplies that were in this responder's possession are returned to $\mathrm{G}-42$.

6. Receive the draft Five Day Final Report from the Team Captain. Review, approve, and submit the Five Day Final Report to the RRC, within four (4) working days. 


\section{Radiological Assistance Program - Incident Report Form}

This form will be filled out by the receiver to the call.

TIME OF CALL:*

DATE :

RECEIVER OF CALL:

TITLE:

ORGANIZATION:

CALLER:

TITLE:

LOCATION OF CALLER:

CONTACT PHONE NUMBER:

\section{INFORMATION RECEIVED}

1. TYPE OF INCIDENT REPORTED (select one)

( ) A. RADIOACTIVE MATERIALS TRANSPORT

() B. NUCLEAR WEAPON ACCIDENT

( ) C. DOE FACILITY

( ) D. NUCLEAR REACTOR

( ) E. OTHER

2. INCIDENT DATE:

INCIDENT TIME:

3. LOCATION OF INCIDENT:

4. BRIEF. DETAILS OF INCIDENT (radiation levels, contamination levels, etc):

5. IS FIRE INVOLVED:

6. OTHER HAZARDOUS MATERIALS:

7. HAS A CORDON BEEN ESTABLISHED AT SCENE: ( ) YES( ) NO

8. KNOWN RADIONUCLIDES:

9. WEATHER CONDITIONS:

*USE 24 HOUR MILITARY TIME 
DOE/RL-97-04-DEL

10. CASUALTIES INVOLVED (include number in brackets):
( ) A. INJURED
B. DEATHS
C. CONTAMINATED
$\left\{\begin{array}{lll}\text { (). } & \text { MISSING } \\ \text { E. } & \text { NONE }\end{array}\right.$

11. RESPONSES CURRENTLY AT THE SCENE (check appropriate):

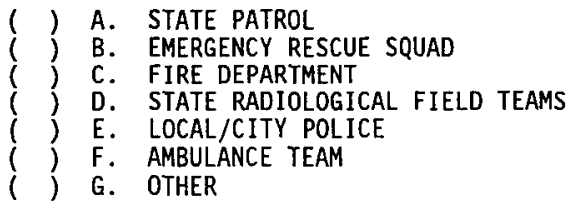

12. TRIBAL, STATE, LOCAL, OR OTHER FEDERAL AGENCIES NOTIFIED:

13. NEWS MEDIA REPORTS OF THE INCIDENT:

ACTIONS TAKEN BY RECEIVER OF CALL

TRIBAL, STATE, LOCAL, AND OTHER FEDERAL AGENCIES NOTIFIED AFTER CALL:

RADIOLOGICAL ASSISTANCE PROGRAM (RAP) TEAM RESPONSE: 
DOE/RL-97-04 -DEL

Safety Plan Checklist

Event Title:

Event Date:

Event Location:

Leader/Team Captain:

Signature:

Safety Items Discussed:

Check if discussed

1. Communications equipment

2. Transportation Safety

a. Land Trave1

b. Air Trave1

c. Water Travel

3. Survey and monitoring equipment

4. First Aid Kit available

5. Drinking liquids available

6. Personnel comfort:

Coats

Rain gear

Protective clothing

7. Fire Extinguisher availability

8. Other

Specific Items Discussed:

1. Liquid Nitrogen

2. Hypothermia

3. Event Scene Hazard Considerations

a. Hazardous Material

1) Radioactive

b. Terrain

2) Toxicological

c. Wind

d. Temperature

e. Precipitation

f. Electrical

g. Mechanical Equipment/Machinery

h. Insects

i. Reptiles

j. Animals 
DOE/RL-97-04-DEL

NOTES: 


\section{Team Leader Checklist}

1. Receive the request for offsite radiological assistance.

2. Record all events and decisions.

3. Call back the requestor, verify the request, and ensure appropriate response agency is notified.

4. Confirm the request for radiological assistance with the appropriate Federal or State agency.

5. Evaluate the request.

6. Decide whether a phone response or a deployment response is required.

7. If a phone response is appropriate, stop here, complete the incident report form and forward it to the RRC.

8. Phone the HQ Emergency 0perations Center (HQ EOC) at (202) 586-8100, to notify them of a request for assistance, ensure that the Team Captain performs this task. Provide the following to the HQ EOC.

- Your name

- Position and titie

- RAP Region 8

- Reason for call.

Note: The HQ EOC shall be notified within 15 minutes after receipt of a request for emergency assistance.

Aiso, the HQ EOC shall be notified if additional assistance or resources are requested from another Regional Coordinating office or when the incident may be subject to significant attention from the media.

9. Report to the EOC (825 Jadwin, G-42) for assembly.

10. Provide briefing meeting before deployment. Complete the Safety Plan Checklist as safety documentation. 
11. Perform on-scene activities.

- Meet with Incident Commander, obtain priorities

- Meet with Team Captain and obtain briefing and status of field team activities and results

- Maintain open communications between Team Captain and Incident Commander.

12. Periodically maintain communications with the Liaison Director.

13. Request additional resources as required.

14. Debrief with the RAP team and summarize incident activities.

15. Debrief with the Incident Commander.

16. Assure that all equipment and supplies that were in this responder's possession are returned to G-42. 


\subsection{TEAM CAPTAIN}

\subsection{PROCEDURE}

At the request of the Team Leader, obtain procedure, $10 \mathrm{~g}$ book and proceed as directed to meet the Team Leader. This procedure will address the steps to be taken when the RAP team has been notified to activate either automatically (i.e., by the ENS) or manually (individual phone call).

\subsubsection{Receive and Evaluate the Request}

1. Assist the Team Leader in evaluating and/or obtaining pertinent radiological data. Assist in determining whether to provide advice over the phone or to deploy the RAP team.

2. Review and/or assist in completing the Radiological Assistance Program - Incident Report Form, attached to the end of this section.

(NOTE: If the Team Leader requests your assistance to notify a cooperating State or Federal agency, use the RAP Team Activation and 24-hour Notification List from Appendix B.

3. If the decision is to provide advice over the phone, no further action is required except to complete the Radiological Assistance Program - Incident Report Form and record all conversation items, in the Team Captain's Log Book. Forward the completed Radiological Assistance Program - Incident Report Form to the Region 8 RRC.

4. If the decision is made to deploy a RAP team, obtain the Team Captain's suitcase and communications equipment. Include any reference material needed from the reference library located in the RAP Ready room. If directed by the Team Leader, call the HQ EOC at (202) $586-8100$, to notify them of a request for assistance. Provide:

- Your name

- Position/title

- RAP Region

- Situation, type of radiological incident and reason for call.

If not already done so, call the POC Duty officer (373-3800) and instruct them to initiate the team activation using the Emergency Notification System (ENS).

5. Report to the EOC and assist the Team Leader as requested.

6. Verify the availability to each position: Team Leader, Team Captain, Liaison Director, Resource Support Manager, Field Team Leader, and Public Information Officer.

7. If responders are unavailable, a responder may assist in a manual call out and/or use extra responders appropriately. If you need to 
find out team availability use the steps in Section 4.2.3 of this manual to initiate an Emergency Notification System print out.

8. Initiate Region 8 RAP Team Position and Deployment List, attached to the end to this procedure. Ensure team is complete.

9. Report the availability of the team members to the Team Leader and obtain a copy for deployment.

10. Attend, participate, and assist in the pre-deployment team briefing.

11. Ensure the Resource Support Manager has prepared the team, vehicles, equipment, and supplies, as applicable.

12. Ensure that logistical considerations are complete (e.g., travel funds, transportation arrangements, hotel reservations, appropriate clothing for changes in weather or night time activities, etc.).

13. Ensure the Field Team Leader and Resource Support Manager have completed their pre-deployment assignments.

\subsubsection{On-Scene Activities}

1. Maintain a chronological record of events and decisions using $R A P$ Team Action Sheet, Appendix A.

2. Ensure that the Field Team Leader has initiated preliminary monitoring of hazards near scene.

3. Arrive at the incident scene and, with the Team Leader, report to the Incident Commander.

4. Obtain any available radiological data from the initial responders and any other potential hazard information.

5. Identify the RAP team's radiological monitoring and assessment capability to the Incident Commander.

6. Determine if a radiological release has occurred.

a. Assess the extent of the radiological incident including, a perimeter survey and air sampling, as applicable.

b. Assess any health hazard to the public and environment.

7. Assist the Team Leader and Incident Commander in establishing radiological monitoring priorities and response team strategies.

8. Brief the Field Team Leader of all known radiological data, any change in incident condition, personnel involvement, or event status. Establish monitoring and survey priorities. 
9. Obtain field team data from the Field Team Leader, assess the data and periodically forward it to the Team Leader and Incident Commander.

10. Periodically provide recommendations to the Team Leader and Incident Commander relative to radiological impacts to the public and the environment.

11. Assist the Team Leader in securing additional resources and/or personnel through the Liaison Director.

\subsubsection{Close-out Activities}

1. Debrief with Field Team Leader to obtain summary of field team activities for use in debriefing the Incident Commander.

2. Debrief with the Team Leader and Incident Commander.

3. Ensure that all field team samples, and radiological waste are collected, appropriately bagged and/or packaged. Walk down the incident scene to ensure DOE, Richland Operations office (RL) property has been retrieved and/or accounted for. Ensure transportation issues have been addressed.

4. Debrief with the RAP team as necessary. Request that all radiation survey reports, team event and decision records, photographs, diagrams, and other pertinent data be completed within two (2) working days of returning home, and forwarded to the Team Captain.

5. Assure that all equipment and supplies that were in this responder's possession are returned to $G-42$.

6. Compile and review the documentation described above, and forward to the Team Leader within three (3) working days of returning home.

7. Assist the Team Leader by initiating preparation of the Five Day Final Report.

\subsection{FIVE DAY FINAL REPORT PROCEDURE}

1. Compile all information concerning the activation. This includes as a minimum the RAP Team Action Sheet(s) from all team members, the Radiological Assistance Program - Incident Report Form, the Region 8 RAP Team Position and Deployment List, the Radiation Survey Report(s), any photographs, maps, drawings, and press releases. The Team Captain is to draft the transmittal letter to DP-20 from the RCO with the Five Day Final Report attached. 
DOE/RL-97-04-DEL

2. The Five Day Final Report should include, at a minimum, the completed Radiological Assistance Program - Incident Report Form, RAP Team Response Chronology Summary, radiation survey report(s), pictures, news articles, and laboratory reports.

\subsection{PROCEDURE FOR ACCESSING ENS}

PERSONAL DATA DELETED 


\section{Radiological Assistance Program - Incident Report Form}

This form will be filled out by the receiver to the call.

TIME OF CALL: **

RECEIVER OF CALL:

DATE:

TITLE :

ORGANIZATION:

CALLER:

TITLE:

LOCATION OF CALLER:

CONTACT PHONE NUMBER:

\section{IMFORMATION RECEIVED}

1. TYPE OF INCIDENT REPORTED (select one)

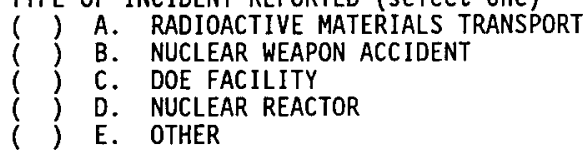

2. INCIDENT DATE:

INCIDENT TIME:

3. LOCATION OF INCIDENT:

4. BRIEF DETAILS OF INCIDENT (radiation levels, contamination levels, etc):

5. IS FIRE INVOLVED:

6. OTHER HAZARDOUS MATERIALS:

7. HAS A CORDON BEEN ESTABLISHED AT SCENE: ( ) YES( ) NO

8. KNOWN RADIONUCLIDES:

9. WEATHER CONDITIONS:

**USE 24 HOUR MILITARY TIME 
10. CASUALTIES INVOLVED (include number in brackets):
( ) A. INJURED
() B. DEATHS
( ) C. CONTAMINATED
( ) D. MISSING

11. RESPONSES CURRENTLY AT THE SCENE (check appropriate):

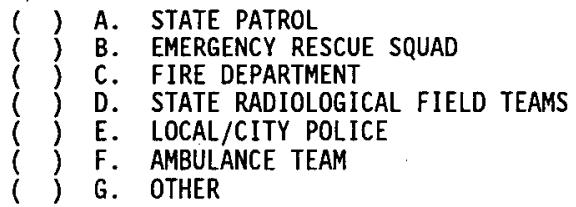

12. TRIBAL, STATE, LOCAL, OR OTHER FEDERAL AGENCIES NOTIFIED:

13. NEWS MEDIA REPORTS OF THE INCIDENT:

\section{ACTIONS TAKEN BY RECEIVER OF CALL}

TRIBAL, STATE, LOCAL, AND OTHER FEDERAL AGENCIES NOTIFIED AFTER CALL:

RADIOLOGICAL ASSISTANCE PROGRAM (RAP) TEAM RESPONSE: 


\section{Region 8 RAP Team Position and Deployment List}

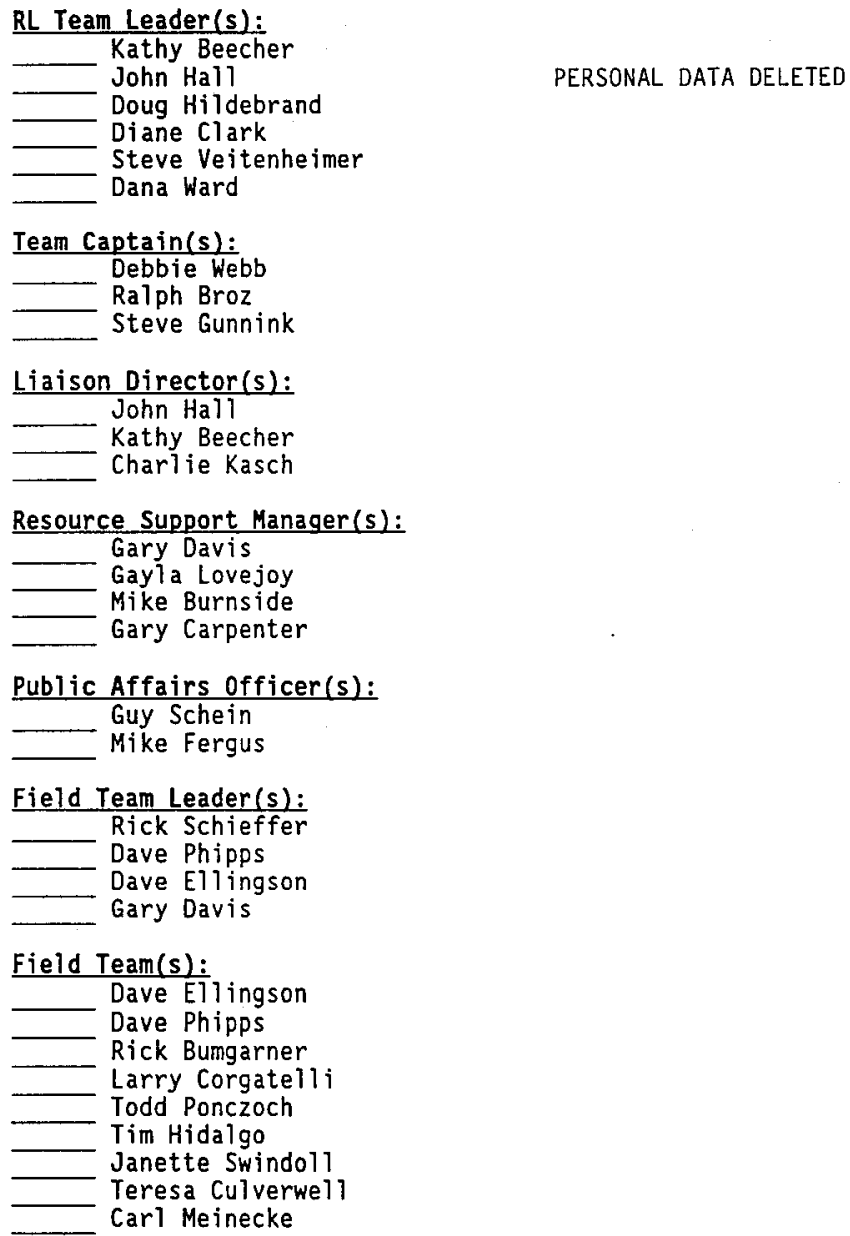

Resource Support Manager(s): Gary Davis

Public Affairs Officer(s): Guy Schein

Mike Fergus

Field Team Leader(s):

Rick Schieffer

Dave Phipps

Dave Ellingson

Gary Davis

Field Team(s):

Dave Ellingson

Dave Phipps

Rick Bumgarner

Larry Corgatelli

Todd Ponczoch

Tim Hidalgo

Janette Swindoll

Teresa Culverwell

Carl Meinecke 
DOE/RL-97-04-DEL

\section{NOTES:}




\section{Team Captain Checkl ist}

\section{Pre-Deployment Actions}

1. If team deployment is required, get the Team Captain's suitcase, cellular phone and if the Team Leader has not activated the RAP Team, notify the POC Duty officer (373-3800) to activate the ENS.

2. Report to the EOC (825 Jadwin, G-42) for assembly.

3. Verify ENS RAP team activation availability list, and report status to the Team Leader.

4. Make manual phone calls as necessary to fill team positions.

5. Attend, participate, and assist in pre-deployment briefing.

6. Ensure the Resource Support Manager has prepared the team, vehicles, equipment, and supplies for deployment.

7. Ensure logistical arrangements are complete before departure.

\section{On Scene Activities}

8. Record all actions, requests, decisions, and follow-up actions.

9. Ensure Field Team Leader has initiated preliminary, near scene radiological surveys.

10. Report to Incident Commander with Team Leader.

11. Obtain available radiological data.

12. Identify RAP team capabilities to Incident Commander.

13. Determine if a radiological release has occurred.

14. Assist in establishing radiological monitoring priorities and team strategies.

15. Brief field team of priorities.

16. Assess field team data, provide recommendation to Team Leader. 


$$
\text { DOE/RL-97-04-DEL }
$$

\section{Close-out Activities}

17. Debrief with Field Team Leader and obtain a summary of field team actions.

18. Debrief with Team Leader and Incident Commander.

19. Assure that all equipment and supplies that were in this responder's possession are returned to $\mathrm{G}-42$.

20. Request that documentation be forwarded to the Team Captain within two (2) working days of returning home.

21. Compile and review chronological documentation; forward to the Team Leader within three (3) days of returning home. 
DOE/RL-97-04-DEL

\subsection{LIAISON DIRECTOR}

\subsection{PROCEDURE}

This procedure will address the steps to be taken when the RAP team has been notified to activate either automatically (i.e., by the ENS) or manually (individual phone call).

\subsubsection{On Receipt of Notification}

1. Report to the EOC (825 Jadwin, G-42) for team assembly.

2. Attend and participate in the pre-deployment briefing.

3. Assist the Team Leader and/or Team Captain with any onsite or offsite notifications. When calling a Federal or State agency, use the RAP Team Activation and 24-hour Notification List, Appendix B.

4. Before the team is deployed, assure receipt of pertinent information i.e., copy of Region 8 RAP Team Position and Deployment List, logistical information, route of travel, and any other pertinent information from the Resource Support Manager.

5. Provide the phone number where you will be stationed to the Team Leader and Resource Support Manager. To assist in establishing and maintaining communications, the following list is normally used.

Patrol Operation Center (POC)

(509) $373-3800$

Occurrence Notification Center

Command Van (Cellular)

EML

RAP Suburban (Cellular)

PERSONAL DATA DELETED

RAP Portable (Cellular)

HQ EOC

\subsubsection{On-Scene Activities}

1. As reasonable, remain available in the EOC. If it is necessary to leave, ensure that the Team Leader, Resource Support Manager, and HQ EOC are aware of the estimated duration and a phone number where the responder can be reached.

2. Establish communication with the RAP Team.

3. Ensure that the RAP Team is informed of pertinent information received from other sources.

4. Make notifications to the $H Q$ EOC as requested by the Team Leader. The HQ EOC phone number is 
5. Notify RL Senior Management that RAP Team has been deployed. Obtain current Duty officer phone number from POC or ONC.

6. Provide information, as requested, to appropriate $\mathrm{RL}$ and other contractor management. If assistance is needed, call the Emergency Duty officer (EDO). The POC (373-3800) can reach the EDO.

7. Assist in obtaining additional resources required by the team. If the team is on a Transportation Security Division response, communications will be through Albuquerque Emergency Operations Center.

8. If additional RAP team members are requested to activate, use the RAP Team Activation and 24-hour Notification List, Appendix B.

9. Record all actions, requests, and follow-up actions on the RAP Team Action Sheet, Appendix A.

\subsubsection{Close-0ut Activities}

1. When on-scene activities are complete, obtain the team's estimated time of arrival back to the EOC.

2. Ensure that all parties initially notified are informed of the team's completed activities.

3. Assure that all equipment and supplies that were in this responder's possession are returned to G-42.

4. Attend the team debrief. Forward all documentation to the Team Captain within two (2) working days. 


\section{Liaison Director Checklist}

1. Receive the notification call.

2. Report to the EOC ( $825 \mathrm{Jadwin}, \mathrm{G}-42)$ for assembly.

3. Attend and participate in the pre-deployment briefing.

4. Assist, as requested, with any notifications.

5. Record all actions, requests, decisions, and follow-up actions.

6. Receive from the Resource Support Manager all pertinent information regarding the team before the team is deployed.

7. Establish and maintain communication with the Team Leader.

8. Secure additional resources, as requested.

9. Notify all parties initially notified of the team's completed activities.

10. Assure that all equipment and supplies that were in this responder's possession are returned to G-42.

11. Compile and review chronological documentation; forward documentation to the Team Captain within two (2) working days. 
DOE/RL-97-04-DEL

NOTES: 


\subsection{PUBLIC INFORMATION OFFICER}

\subsection{PROCEDURE}

This procedure will address the steps to be taken when the RAP team has been notified to activate either automatically (i.e., by the ENS) or manually (individual phone call).

\subsubsection{On Receipt of Notification}

1. Report to the EOC ( 825 Jadwin, G-42) for assembiy.

2. Attend and participate in the pre-deployment briefing.

3. Obtain the Public Information officer kit and any other personally preferred items.

4. Record events and decisions.

5. Obtain information from the Team Leader or Team Captain regarding media or press involvement.

\subsubsection{On-Scene Activities}

1. Attend the initial event briefing with the Team Leader, Team Captain, and Incident Commander if applicable.

2. Keep the Team Leader informed of any media or press related issues pertinent to the RAP team.

3. Obtain Team Leader approval of press releases or other information that is to be made public.

4. Conduct media briefings away from the RAP team as much as possible.

5. Report to the Joint Information Center, if one exits.

6. Obtain all reports and news releases from other sources.

7. Document media and press interfaces.

\subsubsection{Close-0ut Activities}

1. Compile and collect any available media photographs, news releases related to the response, and reports from the scene, and chronological documentation. Include articles obtained from other sources, if applicable. 
2. Attend the team debrief. Forward all documentation to the Team Captain within two (2) working days of returning home.

3. Assure that all equipment and supplies that were in this responder's possession are returned to $\mathrm{G}-\mathbf{4 2}$. 


\section{Public Information Officer Checklist}

1. Receive the notification call.

2. Report to the EOC ( 825 Jadwin, G-42).

3. Attend pre-deployment briefing.

4. Obtain Public Information Officer kit.

5. Record events and decisions.

6. Provide media and press communications while at the incident scene.

7. Assure that all equipment and supplies that were in this responder's possession are returned to $\mathrm{G}-42$.

8. Compile all chronological documentation, press releases, and photographs; forward them to the Team Captain within two (2) working days. 
DOE/RL-97-04-DEL

NOTES: 


\subsection{RESOURCE SUPPORT MANAGER}

\subsection{PROCEDURE}

This procedure will address the steps to be taken when the RAP team has been notified to activate either automatically (i.e., by the ENS) or manually (individual phone call).

\subsubsection{On Receipt of Notification}

1. Report to the EOC (825 Jadwin, G-42) for assembly.

2. Make travel and logistical arrangements as applicable.

3. Attend and participate in the pre-deployment team briefing.

4. Coordinate and prepare response vehicles for deployment.

5. Before the team is deployed, assure a copy of Region 8 RAP Team Position and Deployment List, logistical information, route of travel, and any other pertinent information is provided to the Liaison Director.

6. Coordinate and document in the log, distribution of deployed equipment. Make a copy of the $\log$ and leave in the RAP Ready Room.

7. Coordinate communication link between Liaison Director and team.

8. Verify communications between deployed vehicles.

9. Ensure that the Liaison Director is aware of team destination and mode of travel.

\subsubsection{On-Scene Activities}

1. Arrive at the incident scene and set up the Command Van, if applicable.

2. Assist, as requested, the Team Leader and Team Captain in securing open communications with the Liaison Director.

3. Complete the chronological record of events affecting this position and related requests.

\subsubsection{Close-out Activities}

1. Assist the field team in collecting and assembling used equipment and supplies in preparation for returning home. 
2. Disassemble communication, mechanical, and/or electrical supplies and resources.

3. Ensure that all DOE-owned material, equipment, and supplies are packed and prepared for travel.

4. Attend and participate in a team debrief.

5. Assure that all equipment and supplies are returned to $G-42$ and are ready for the next deployment.

6. Request that all team members provide a list of supplies and equipment that require replacement and/or maintenance.

7. Complete and forward RAP chronological record to the RAP Team Captain within two (2) working days of returning home. 
DOE/RL-97-04-DEL

\section{Resource Support Manager Checklist}

\section{Pre-Deployment Actions}

1. Report to the EOC ( $825 \mathrm{Jadwin}, \mathrm{G}-42$ ).

2. Make travel and logistical arrangements as applicable.

3. Attend and participate in the pre-deployment team briefing.

4. Complete the chronological record of events affecting this position and related requests.

5. Coordinates and prepares response vehicles for deployment.

6. Before the team is deployed, assure a copy of Region 8 RAP Team Position and Deployment List, logistical information, route of travel, and any other pertinent information is provided to the Liaison Director.

7. Coordinate and $\log$ distribution of deployed equipment. Make a copy of the $\log$ and leave in the RAP Ready Room. Verify communications between deployed vehicles.

8. Coordinate communication link between Liaison Director and team.

9. Verify communications between deployed vehicles.

\section{On-Scene Actions}

1. Set up Command Van, portable weather station, and communications systems operation, if applicable.

2. Assist as required by the Team Leader and Team Captain in securing communications with Liaison Director.

4. Assist the Team Captain in securing additional resources and/or personnel if required.

5. Compile all chronological documentation and forward them to the Team Captain within two (2) working days.

Phone Numbers

Patrol Operation Center (POC)

Occurrence Notification Center

(509) $373-3800$

Command Van (Cellular)

EML

RAP Suburban (Cellular)

RAP Portable (Cellular)

HQ EOC

PERSONAL DATA DELETED 
DOE/RL-97-04-DEL

NOTES: 
DOE/RL-97-04-DEL

\subsection{FIELD TEAM LEADER}

\subsection{PROCEDURE}

This procedure addresses the steps to be taken when the RAP team has been notified to activate either automatically (i.e., by the ENS) or manually (individual phone call).

\subsubsection{On Receipt of Notification}

1. Notify and assemble the field team(s). If the activation is during the off-shift, assembly will take place at the EOC.

2. Report to the EOC ( $825 \mathrm{Jadwin,} G-42)$.

3. Attend and participate in the pre-deployment team briefing.

4. Prepare field team for deployment. Attempt to call field team members who have not responded to the EOC. Field team members should attempt to call if they cannot respond to the center.

5. Assure the field team members are assembling applicabie instrumentation kits and all other health physics related supplies.

6. Personnel protective equipment is issued in accordance with established Radiation Worker and any other hazardous condition requirements. This would include clothing, respiratory equipment, dosimetry, and any other kits.

7. Assign personnel dosimetry to RAP team members using the Region 8 RAP Team Position and Deployment List. The Team Captain has already initiated this list for team accountability status.

8. Once the Region 8 RAP Team Position and Deployment List is complete, make a copy of the list. Give a copy to the Liaison Director and the original to the Team Captain.

\subsubsection{On-Scene Activities}

1. Obtain from the Team Captain all known radiological, other hazardous material data, any change in incident condition, personnel involvement, or event status.

2. Complete a chronological record of events and decisions.

3. Provide direction to the field teams.

4. Consult with the Team Captain on radiological survey priorities and assessments. 
5. Provide assessed radiological and other hazardous material data to the Team Captain.

6. Maintain communications with the Team Captain.

\subsubsection{Close-0ut Activities}

1. Debrief with the field team(s).

2. Debrief with the Team Captain.

3. Assure all field team material and equipment is prepared for departure.

4. Review, approve, and collect all documentation produced by the field team.

5. Assure that all equipment and supplies are returned to G-42 and are ready for the next deployment.

6. Debrief with the RAP team. Request that Radiation Survey Reports, and other record sheets are completed within two (2) working days from returning home and forwarded to the Team Captain. 
DOE/RL-97-04-DEL

Field Team Leader Checklist

1. Receive the notification call.

2. Notify and assemble the field team(s).

3. Report to the EOC ( $825 \mathrm{Jadwin}, \mathrm{G}-42$ ) for assembly.

4. Attend and participate in the pre-deployment team briefing.

5. Review safety and health issues and/or concerns with the team.

6. Understand and acknowledge all known hazards and weather conditions.

7. Assign personnel dosimetry to all responding RAP team members.

8. Prepare the field team for departure. Attempt to call field team members who have not responded to the EOC. Field team members should attempt to call if they cannot respond to the center.

9. Secure required health physics and radiation protection instrumentation, dosimetry, and related equipment and supplies. Assure operability and calibration of instrumentation.

10. Begin hazardous material measurements before arriving on scene to establish background and or changing conditions.

11. Upon arrival at the scene, obtain from the Team Captain all known radiological data, changes in incident conditions, personnel involvement, or overall event status.

12. Provide direction to the field team(s).

a. Ensure that a perimeter survey is accomplished.

b. Ensure that air sampling if needed is accomplished.

c. Ensure that staging area and event scene personnel are in safe condition.

d. Ensure that priorities for field teams is communicated to team members.

13. Assist the Team Captain with radiological assessments and review and verify all field team data.

14. Close-out on-scene field team activities.

15. Debrief with field team(s); collect all radiation survey reports, RAP Team Action Sheets, logs etc. Assure that field team members document any lessons learned from RAP response. 
16. Upon arrival at the EOC, debrief with the RAP team. Ensure that field team members provide a list of used equipment and supplies in need of replacement, and forward to the Resource Support Manager.

17. Ensure hours of work, expenses and other contractual obligations are appropriately documented.

18. Assure that all equipment and supplies that were in this responder's possession are returned to $\mathrm{G}-42$.

19. Compile and review documentation, including chronology; forward to the Team Captain within two (2) working days of returning home.

20. Schedule and attend a Lessons Learned meeting for RAP Team responders. 
DOE/RL-97-04-DEL

\subsection{BIBLIOGRAPHY}

Public Law 83-703, Atomic Energy Act of 1954, as amended.

DOE 0 151.1, 1995, Comprehensive Emergency Management System, U.S. Department of Energy, Washington, D.C.

DOE Order 5530.3, 1992, Radiological Assistance Program, U.S. Department of Energy, Washington, D.C.

FEMA, 1996, "Federal Radiological Emergency Response Plan," 61 FR 20944, Federal Register, Vol. 61, p. 20 (May). 
DOE/RL-97-04-DEL

This page intentionally left blank. 
DOE/RL-97-04-DEL

\section{APPENDIX A RAP Team Action Sheet}

RAP Team Member:

Print Name:

Signature:

Incident Date:

Incident Location:

TIME

ACTION TAKEN

RESULT/FOLLOW-UP 
DOE/RL-97-04-DEL

MOTES:

A-2 
APPENDIX B RAP Team Activation and 24-Hour Notification List

\section{REGION 8}

RADIOLOGICAL ASSISTANCE PROGRAM

\section{Region 8 Regional Response Coordinator:}

Kathy Beecher

PERSONAL DATA DELETED

Region 8 Radiological Assistance Program, Coordinator:

Debbie Webb

RL Team Leaders (call in order):

Kathy Beecher

Doug Hildebrand

Diane Clark

John Hall

Dana Ward

Steve Veitenheimer

Team Captains:

Debbie Webb

Ralph Broz

Steve Gunnink

Liaison Director:

John Hall

Kathy Beecher

Charlie Kasch

Resource Support Manager:

Gary Davis

Gayla Lovejoy

Mike Burnside

Gary Carpenter

* NOTE: The RL pagers starting with 800 or SKYPAGERS starting with 888 cannot be activated with a computer, you must use the telephone. 
Public Affairs Officer:

Guy Schein

Mike Fergus

* NOTE: The RL pagers starting with 800 or SKYPAGERS starting with 888 cannot be activated with a computer, you must use the telephone.

NOTE: Hanford pagers can be called using the HLAN Pager icon onsite, calling or when offsite.

Field Team Leader:

Rick Schieffer

Dave Phipps

Dave Ellingson

Gary Davis

Field Team members: Radiological Control Technicians (RCTs) are not on the ENS and therefore need to be manually called by the Field Team Leader when ENS is activated. The Field Team Leader is responsible and will most likely call RCTs prior to reporting to the ONC.

On-shift, RCTs can be reached by calling:

off-shift, RCTs home phone numbers and pagers:

Dave Ellingson

Dave Phipps

Rick Bumgarner

Larry Corgatelli

Todd Ponczoch

Tim Hidalgo

Janette Swindoll

Terry CuTverwe]1

Carl Meinecke

Environmental Mobil Laboratory

Jennifer Tanner

Dan Haggard

Bill Endres

Pete Eschbach

Steve Miller

Lowell Nichols

Dan Sisk

Kelvin Soldat

Paul Tomeraasen 
Other pertinent information:

POC

ONC

DYN EDO

(for non-emergency) (5 AM - $7 \mathrm{PM}$ )

and request the ONC Call the EDO for you

RAP Cellulars:

$4 \times 4$ Command Suburban

Equipment Suburban

EML Truck

Command Van

Portables

Mobil Bag Phones

Portables

Keys to the Suburban, Command Van, Dual-Wheel Truck, and the Emergency Mobile Laboratory are in the RAP Ready Room (G42), in the brown key case in the desk organizer.

24-hour Emergency Notification Phone Numbers:

DOE HQ Emergency Operation Center Duty Officer:

Regional Coordinating offices:

Brookhaven

Oak Ridge

Savannah River

Albuquerque

Chicago

Idaho

Oakland

Richland

Additional DOE Emergency Response Assets:

Accident Response Group (ARG):

Aerial Measuring System (AMS):

Atmospheric Release Advisory Capability (ARAC):

Federal Radiological Monitoring \& Assessment Center (FRMAC):

Nuclear Emergency Search Team (NEST):

Radiation Emergency Assistance Center/Training Site(REAC/TS): 
Federal and States 24-Hour Emergency Notification Phone Numbers

U.S. Department of Transportation Bennie Walthall

Regional Emergency Transportation Rep.

Region $X$

915 2nd Ave. Rm. 3590

Seattle, WA 98174-1067

U.S. Department of Interior

Pamela A. Bergman

Office of Environmental Affairs

1689 C Street, Room 119

Anchorage, AK 99501-5126

U.S. Department of Interior

Office of Environmental Review

Preston Sleeger

500 NE Multnomah St., Suite 600

Portland, OR 97232

U.S. Environmental Protection Agency Jerrold Leitch

Region $X$

Seattle, WA 98101

Federal Emergency Management Agency Larry E. Moore Region $X$

130 228th St. SW

Bothe11, WA 98021-9796

U.S. Nuclear Regulatory Commission Ann Mattila

Region IV

Harris Tower \& Pavilion

611 Ryan Plaza Drive, Suite 400

Arlington, Texas 76011-8064

Washington State Department of Health Duty Officer: (NUCLEAR) Oregon Emergency Response System (OERS):

Alaska Division of Emergency Services: 


\section{RESOURCE ITEM}

Air Sempler, Gas/Particulate High volume, Staplex Model Medium volume, HI-Q Model cF-

Medium volume, HI-Q Model CF-
air Sampler Impactor Collector

High volune, Staplex Model IF1A, 0-70 CFM, requires $110 / 115$ volt, AC

Analytical Lab, Mobile

- Also has Harshaw 3500 for TLD readout

Anti-c clothing

Bags, Plastic

Batteries, Cellular

Banner, Tape

\section{Blankets}

Binoculars

Calculators

Camera

Cellular Phones

Chairs, folding

Command Van

Communications

Computer, Laptop

Cone, Orange

\section{Dictaphone}

Dosineter, Charge

Dosimeter, Pocket

Gama, self-reading, 0-500mr range Dosimeter, Personnel Badge

Fax Machine full sets - cloth

Miscel laneous assor tment

Extra Battery

"Caution" $1000 \mathrm{ft}$

Nool

10 Power $\times 50 \mathrm{~mm}$

7 Power $x 25 \mathrm{~mm}$

Various hand held types

$35 \mathrm{~mm}$, Polaroid

Portable

\section{Camping type}

stocked to serve as a command post at accident site

See radios, telephones, etc.

Windows, remote cc:Mail capability, UP, Hanford phone directory

Road safety type

Mini-talk tape recorder

For self-reading pencils

20 , self-reading, 0 -200mr range

ILO - for beta/gama/neutron

Communication with other agencies *initial guANTIIY 
DOE/RL-97-04-DEL

NOTES :

C-2 
Region 8 Radiological Assistance Program - Deployable Resources

\section{RESOURCE 1TEM}

First Aid kit

Flares, Safety

Flashlights

Generators, Portable

Glasses, Safety

Gloves, Various

Global Position System

Hard Hats

Instruments, Radiological

CP

- alpha count rate meter uith scintill probe

Fidler a lpha count rate meter, with scintillation probe

Ficror energy radiation detector, with MCA

Micro/k thin window gamina ...

Jackets

Winter Carharts with hoods

Lantern

Maps, Topo

Mobile Comand Post

Potassium lodide Tablets

Propane - double mantel, Camping type

Alaska, Idaho, Oregon, Hashington - Atlas Gazetteer

See Command Van

located in Field Team Go-kits

Radio, Mobile

GE, Model HNJohnson, , Moded

Radio, Portable Motorola, Low

GE, Model Phoenix SK, located in Suburban, Command Van in suburban, Commend ven Suburban, Command Van

eam Position Kit

$.00 \& 46.58 \mathrm{MHz}$

Ribbon

Includes office supplies, procecture

Various colors for marking locations
*IMITIAL QUANTITY

5

3

12

2

12

4

7

* Denotes quantity initially available - additional may be available.

\begin{tabular}{|c|c|c|}
\hline \multicolumn{3}{|c|}{ ACIIVATION INFO } \\
\hline HRS & ROAD & Air \\
\hline $1-2$ & $x$ & $x$ \\
\hline $1-2$ & $x$ & $x$ \\
\hline $1-2$ & $\mathbf{x}$ & $x$ \\
\hline $1-2$ & $x$ & $x$ \\
\hline $1-2$ & $x$ & $x$ \\
\hline $1-2$ & $\mathbf{x}$ & $x$ \\
\hline $1-2$ & $x$ & $x$ \\
\hline $1-2$ & $x$ & $x$ \\
\hline $1-2$ & $x$ & $x$ \\
\hline $1-2$ & $x$ & $x$ \\
\hline $1-2$ & $x$ & $x$ \\
\hline $1-2$ & $x$ & $x$ \\
\hline $1-2$ & $x$ & $x$ \\
\hline $1-2$ & $x$ & $x$ \\
\hline $1-2$ & $x$ & $x$ \\
\hline $1-2$ & $\mathbf{x}$ & $x$ \\
\hline $1-2$ & $x$ & $x$ \\
\hline $1-2$ & $\mathbf{x}$ & $x$ \\
\hline - & - & - \\
\hline - & - & - \\
\hline $1-2$ & $\mathbf{x}$ & $M / A$ \\
\hline $\begin{array}{l}1-2 \\
1-2\end{array}$ & $x$ & $x$ \\
\hline $1-2$ & $x$ & $x$ \\
\hline $1-2$ & $x$ & $x$ \\
\hline $1-2$ & $\mathbf{x}$ & $x$ \\
\hline
\end{tabular}


RESOURCE I TEM

Remote Handling Tools

Rope, Radiation

shower

Table

Tape

Tarp

Telephones
Tongs, 12 inches long

Mylon, Yellow and Magenta

$\mathrm{H}_{2} \mathrm{O}$ Sun Shower Enclosure, Camping type

fold-out-table, four person, Camping type

Various types - duct, masking, radiation

$108 \mathrm{sq}$. ft. ( 4 yd $\times 3$ yd)

Portable, Cellular

Mobile, located in suburben and command Van

IMMARSAT, International Maritime Satellite Telecommunications

Tents

Toilet

Tools, Hand

video, Cancorder

Vests

Vehicles

Nalking sticks

Water, Coolers

Weather station

Wind Speed Indicator

Camping, 4 man capacity

Port-a-potie, Camping type

Various assortment

Still video system, with View-Com-Teleport, Sharp Hodel VL-H4100

Safety Orange Vests

Suburban $4 \times 4$, Command Van, Dual theeled Truck

for performing ground surveys

Various sizes

Portable, located in Command Van

Portable, Hand held
* InITIAL QUANTIIY

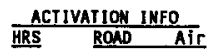

$1000^{\circ}$

2

1

$-$

3

2

2

2

1.

1

-

2 